Contents list avaliable at Directory of Open Access Journals (DOAJ)
Aulad : Journal on Early Childhood
Vol 3 No 12020, Pages 8-13
ISSN : 2655-4798 (Printed); 2655-433X (Online)
Journal Homepage: https://aulad.org/index.php/aulad

\title{
Traditional Game of Ular Naga for Early Childhood Development from Teacher's Perspective
}

\author{
Avanti Vera Risti Pramudyani ${ }^{1}$ \\ Pendidikan Guru Pendidikan Anak Usia Dini, Universitas Ahmad Dahlan \\ DOI: 10.31004/aulad.v3i1.48
}

Article Info

Keywords:

ular naga

teacher's perspective

development aspect

early childhood

\author{
Kata kunci: \\ ularnaga \\ perspektifguru \\ aspek perkembangan \\ anak usia dini
}

\begin{abstract}
The traditional game Ular Naga is one of the traditional games from the Yogyakarta region, these games can be a method to create joyful learning and can develop many aspects of early childhood. This study aims to know the benefit of traditional games of Ular Naga for early childhood teacher perspective in early childhood education. This research is qualitative research with early childhood teacher as the subject and to collecting the data with the interview, observation, and documentation. Validation data used triangulation technique. Analysis of data such as collected data, reduction data, display data and make a conclusion. The result shows that the majority of the teacher's perspective has the same argument that Ular Naga has the benefit of developing an aspect of the children such as gross motor skills with activities walking, running, catching, make a train, and make a line and social-emotional aspects with activities build cooperative within friends in the group. However the teacher not yet explanation holistically all the aspect that should be can develop from Ular Naga.
\end{abstract}

\section{Abstrak}

Permainan tradisional Ular Naga adalah salah satu permainan tradisional dari daerah Yogyakarta yang dapat digunakan sebagai salah satu metode untuk menciptakan pembelajaran yang menyenangkan dan mengembangkan seluruh aspek perkembangan dalam diri anak usia dini. Penelitian ini bertujuan untuk mengetahuai manfaat permainan tradisional Ular Naga bagi anak usia dini dilihat dari pendapat guru. Penelitian ini adalah penelitian kualitatif deskriptif dengan subjek penelitian guru PAUD dan instrumen pengumpulan data melalui wawancara, observasi dan dokumentasi tentang perspektif guru dari permainan tradisional yang dapat mengembangkan aspek anak. Keabsahan data menggunakan triangulasi teknik. Analisis data penelitian ini meliputi pengumpulan data, reduksi data, penyajian data, dan penarikan kesimpulan. Hasil penelitian ini menunjukkan mayoritas guru berpendapat bahwa permainan tradisional Ular Naga memiliki manfat untuk mengembangkan aspek perkembangan anak meliputi motorik kasar yaitu berjalan, berlari, menangkap, membuat kereta dan barisan; serta pada sosial emosional anak dapat mengembangkan kemampuan koorperatif atau berkerjasama antar teman dalam kelompok yang sama. Namun guru belum mampu menjelaskan secara holistik keseluruhan aspek yang dikembangkan oleh permainan tradisional Ular Naga.

\footnotetext{
${ }^{1}$ Corresponding author at: Pendidikan Guru Pendidikan Anak Usia Dini, Universitas Ahmad Dahlan, Jalan Ki Ageng Pemanahan No. 19 Yogyakarta, Indonesia.

Email address: avanti.pramudyani@pgpaud.uad.ac.id
} 


\section{INTRODUCTION}

Indonesia is a country with very diverse cultural elements, especially traditional games. Based on identification data conducted by Dharmamulya, et al, (2005), in Yogyakarta Special Region there are 40 traditional games that are still played or never played by children. The forty traditional games have different characteristics and different goals according to the type of game being played. According to the Directorate of Cultural Values cited by (Kurniati, 2016), the traditional game consists of two classes: traditional games to play, and traditional games to compete. The traditional game to compete for consists of three categories which are; (1) the game is strategic, (2) the game gives priority to physical play, and (3) the game has speculative character.

Traditional games are not only able to develop characters, but also contribute to the development of aspects in children who play it. Games can be grouped into 5 categories based on the meaning it is contained therein; (1) games that are performed imitation to actions, (2) games attempt the strength and skill, (3) games of senses, (4) games of language practice, and (5) games with motion and rhythm (Dharmamulya, 1993). Each traditional game has a goal that is able to develop all aspects of development in the children.

The traditional games are one of the cultural activities that contain cultural values of a particular area and is taught from generation to the next generation. Children can develop potential, gain meaningful experiences, add vocabulary, build relationships, channel emotions, and preserve the culture by playing activities of traditional games. This is in accordance with the opinions of (Ulker, R., \& Gu, 2004), playing traditional games is an activity passed down from generation to generation and done by most people. The traditional games are very suitable for children to develop their aspect of developmental.

Children who played traditional games without them know they also learn to develop their potentials. According to Sugiarto, as quoted by (Kurniati, 2016), playing is children's scientific activities conducted without coercion. According to Frobel, playing that commonly called children's work, is an activity that can help them transfer happiness, excitement, and pleasure to play into the adult working world. Playing is children's activity involving time, energy, and previous experience to develop their talents and abilities. By playing the children are able to develop physical, social, and intellectual abilities.

All this time, traditional games are only considered as games that are additional activities on the curriculum developed by the school. Even traditional games are considered games when the children have free time or celebrate a special occasion. Other obstacles encountered in implementing traditional games in the learning process are the views of parents, teachers, or school parties who consider that games are a time-wasting activity. While the physical barrier is more due to the lack of space or land to play traditional games, as we know this game requires a large enough land (Kurniati, 2016).

Traditional games do not only facing a lack of space or become supplement activities on learning. The teacher also does not understand that the learning activities in the form of games are able to develop all aspects of development in children. Based on the results of a survey to the teacher at ECE in the Special Region of Yogyakarta obtained information that only $32 \%$ of educators who understand the six aspects of development in children can be developed in games activity, the rest still use the old pattern in which one activity one aspect of development (Pramudyani, A. V. R., Kurniawan, M. R., Rasyid, H., 2017).

Ular Naga as one of the traditional games at Yogyakarta has been known as games that only can develop motor skills. According to the research results (Cahhya, M. S., Parmiti, D. P., \& Mahadewi, 2017), the game of Ular Naga can develop ability on the coordinate movement of the head-hand-foot children in group B Kindergarten. It is indicated that the teacher does not know that other aspects of early childhood can develop through traditional games Ular Naga.

Ular Naga is a traditional game that can develop several aspects of the children not only motor skill. According to the (Prihariyani, 2018), Ular Naga is a game that effective to develop language skills for the student to express their verbal language. This games also can be methods to develop a social aspect for children. With Ular Naga, children can improve the social development of children in collaboration, responsibility, and tolerance (Syafrina, 2014). Moreover, Ular Naga also can be ways to teach children washing their hands. According to (Cahya, K. D., Mauliyana, A., Fitriyaningsih, R., Widayanti, T. A., Dewi, W. S., \& Noviani, 2019), games of Ular Naga can be used as stimulation for children after they finish playing the games to wash their hand because they touch their friends.

The traditional games like Ular Naga not only develop aspects of children but also can be the methods for the teacher to create joyful learning activities. According to (Stojanovska, T. V., Connell, V. M., Malinovski, T., \& Trajkovik, 2014), the games based learning encouraged active participation the students in the games, collaboration, and cooperative work on problem solving, development of critical thinking, praising the friendship during joyful learning activities. Even though traditional games has many advantages for children and becomes the main methods of the teacher in class, instead they only used the games as additional activities.

This study aims to know about the teacher's opinions at Early Childhood Education about traditional games Ular Naga as the main activity on their learning process and the benefit for children to develop their aspect. 


\section{THEORY}

\section{Traditional Games Ular Naga}

Ular Naga is one of the traditional games played without tools and these games only need outdoor spaces or field. Playing these games need 5 until 15 children and will be more fun if the members more than that. The movement of these game mostly copying snake's move (Kurniati, 2016).

\section{How To Play}

According to (Pramudyani, A. V. R., Kurniawan, M. R., Rasyid, H., Sujarwo, S., Utami, N. I., \& Rachmawati, 2018) and (Dharmamulya, dkk, 2005), traditional games Ular Naga have a lot of activities such as singing, playing, and dialogue. Playing games of Ular Naga we can following these steps:

a. Collecting members from 5 - 15 children and choose 2 children to become a leader and make a tunnel with their hands. The member will be choosing 2 children to become tunnel and the mother or leader of the group. Every mother or leader decided their group's name.

b. When the children start to play they sing the Ular Naga's song. The tunnel will catch one of the children when the song is stopped. The children who traped on the tunnel will be asked from the mother or leader to pick one of them. This step will be containing until all the children have a group.

c. After all the members have a group, the group with the less member will be the one who attacks another group and take one member who they can be caught to be their group.

d. The winner is the group with the amount of the members more than another group.

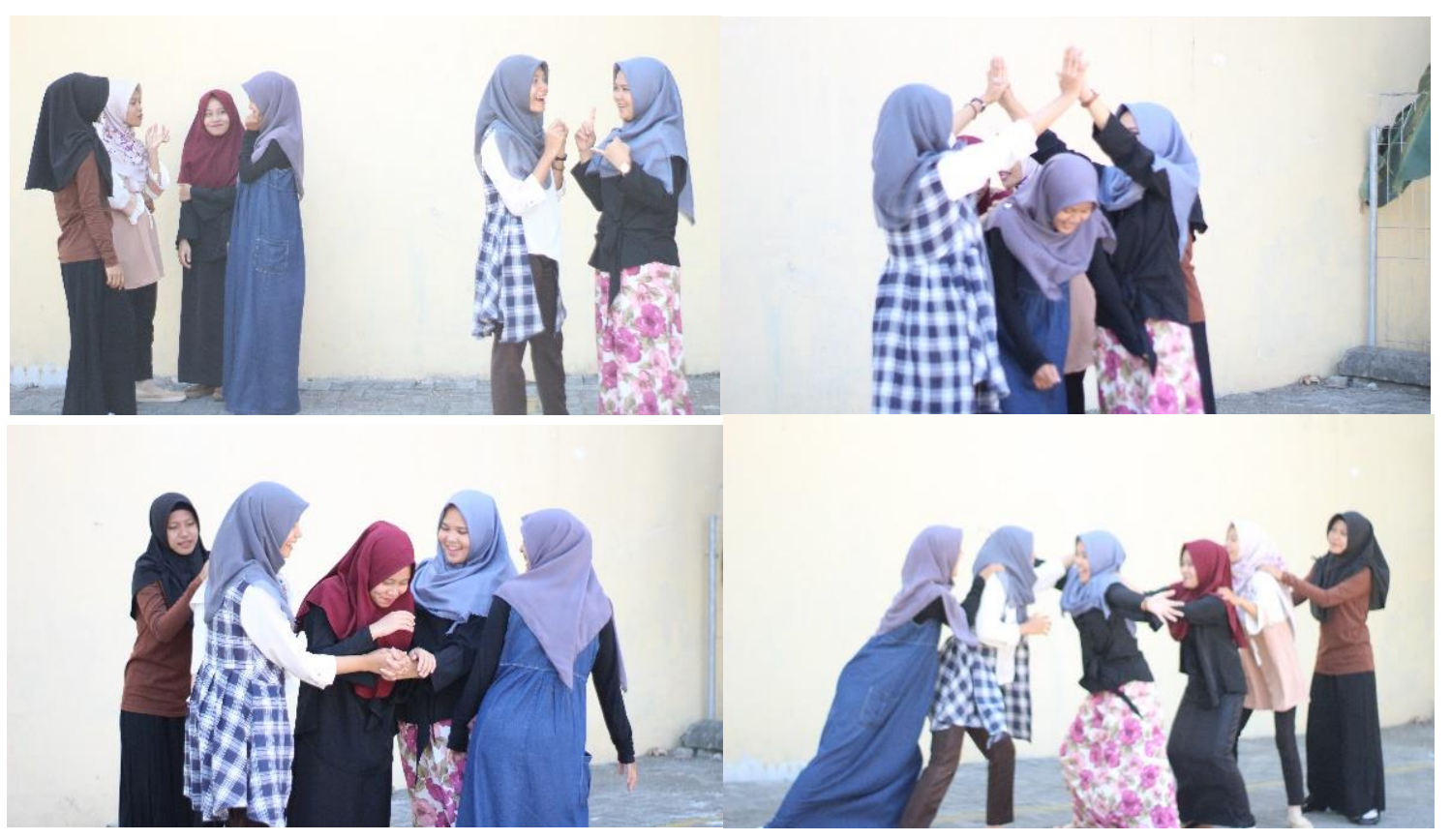

Picture 1. Playing Ular Naga Games

\section{The aspect of Ular Naga for Children}

Traditional games Ular Naga can be the ways to developing aspect on the children such as socialemotional aspect for examples cooperative, leadership, respecting; for the language, the children will learn how to communicate; and gross motor skills. However, if we examined more deeply, can develop all aspects of childhood development. The aspect that can be developed from these games are:

a. Religious and Moral Values: the child is able to develop the ability to understand the rules, they learn to feel free with the activities, understand the reward and punishment.

b. Cognitive: the children are able to develop the measurements according to their height and understand the shape of a symbol when making line like a dragon.

c. Language: they involved in a short conversation and give a response the other child that has been caught, develop expression ability, they can express their happiness when they win the game or disappointed when they lose or while on game.

d. Gross and Fine Motor: the children are able to develop gross motor skills with activities walking, turn left or right, up and down the arms, and make a tunnel; They are also able to develop fine motor skills with holding the hand and grab the friends shoulder. 
e. Social emotional: they can show the feeling of love for friends with protecting them from the other group, they are can learn and practices in managing their emotions when lose or win, and leadership especially when the become leader on the group.

(Pramudyani, A. V. R., Kurniawan, M. R., Rasyid, H., Sujarwo, S., Utami, N. I., \& Rachmawati, 2018)

Based on those theories, Ular Naga is traditional games with various activities that can be played from 5 15 children. The benefit if the children playing this game are developing 5 aspects in them such as religious and moral value, the children will be understanding about rules; cognitive, learn about symbolic, language, communication and expressing language; motor skills both gross motor and fine motor; and social-emotional, leadership, controlling emotion, affection to their friends.

\section{RESEARCH METHODS}

This research is a type of qualitative research with a descriptive approach to describing the benefit of traditional games Ular Naga on children's aspect development from the teacher's perspective. The subject of this research are 40 early childhood teachers in 4 areas Yogyakarta, Bantul, Sleman, and Gunung Kidul.

Data collected from the interview, observation, and documentation. The technique of data analysis that the researcher used was a descriptive analysis, that was analyzed and gave interpretation to collected. Furthermore, the result of the descriptive analysis will be classified from the general facts in a special direction, so that the reconstruction results were presented more specifically (Miles, M. B., Huberman, M. A., \& Saldana, 2014).

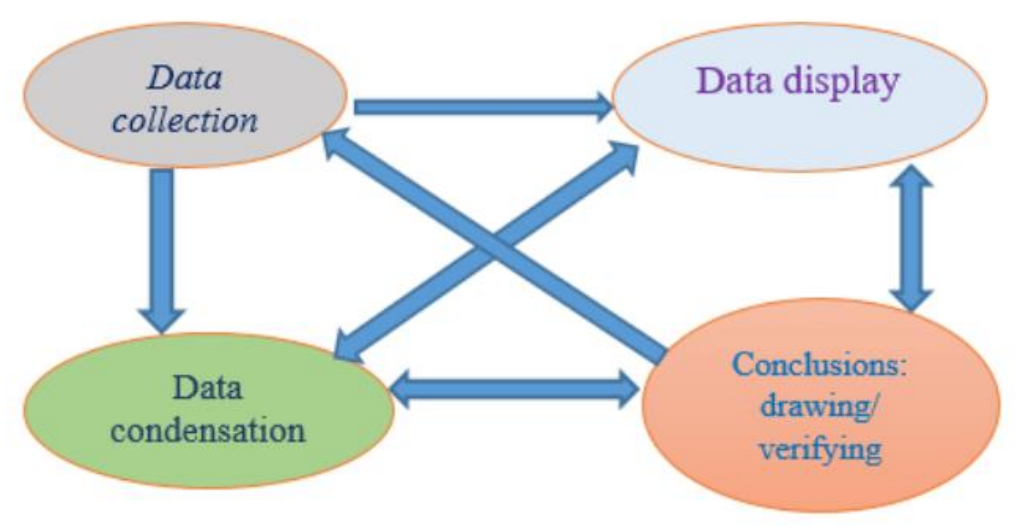

Picture 2. Analysis Data

(Miles, M. B., Huberman, M. A., \& Saldana, 2014)

\section{RESULT AND DISCUSSION}

In accordance with the data, the results of the interview, observation, and documentation, it can be asserted as follows;

First, from the data obtained information that 40 teachers as the respondent have applied the traditional games in children's play activities at school. From these data, it can be seen that the resource persons as an early childhood teacher know that traditional games is beneficial for the children and preserving the culture. Even though traditional games can be played at school they only doing these games when the children waiting to start learning activities or when waiting to be picked up by their parents. From the data, the respondents have not fully understood the usefulness of traditional games. Benefits obtained by children in doing traditional games is the same as other learning activities, in which able to develop the overall aspects of children's development. This is in accordance with the results of the research by (Suherman, W. S., Nopembri, S., \& Muktiani, 2017), which stated that the Model of Educational and Attractive Physical Activity games based on children's dolanan (playing) is able to optimize the growth of kindergarten students.

Traditional games in addition to providing benefits for children to channel their energy, and develop aspects of development. Traditional games as part of the core activities of the learning process can build the children's motivation to learn. As the result of research by (Nasrullah, 2015), which stated that the design of learning using traditional games Bermain Satu Rumah (Playing a Home) in learning activities can motivate students to follow the learning activities and stimulate students in learning materials.

Secondly, the data show that the respondent has not fully understood that traditional games can develop all aspects of development including religious and moral values, cognitive, language, motor, emotional, social, and arts. For resource persons, traditional games are still understood as a game with the benefit of only developing only physical ability. Only $35.48 \%$ of respondent persons are agreed that traditional games are capable of developing all aspects of development that exist within Early Childhood children. In accordance with the results of the research by(Suherman, W. S., Nopembri, S., \& Muktiani, 2017), which stated that traditional games can optimize the growth of children covering six aspects of development, which are: (1) cognitive, (2) motor physical, (3) language, (4) ) social-emotional, (5) arts and creativity, and (6) moral and religious values. 
Third, from the data that respondent state uncommon playing Ular Naga as main activities of the learning process in the class or schools. An only respondent that teaching on the suburban who have open spaces. Moreover, they playing Ular Naga once in a couple a week. The reason the respondent is uncommon to play Ular Naga are they lack spaces especially at Yogyakarta City, they also do no have field at school. According to(Kurniati, 2016), the reason Ular Naga is rare to play especially for school who located at the city is a physical barrier, they do not have open spaces or field to cover this game.

Fourth, $75 \%$ of the respondent agree that Ular Naga has capable of developing cognitive aspect on children when counting the members on the group. Even they know Ular Naga gives chance to develop cognitively aspect, they can not explain more the other competencies. Playing Ular Naga for children can develop their cognitive competencies such as learn to understand a symbol when they make a line. The line represents the body of a dragon (Naga) that can make a movement (Pramudyani, A. V. R., Kurniawan, M. R., Rasyid, H., Sujarwo, S., Utami, N. I., \& Rachmawati, 2018).

Five, from the data $85 \%$ respondent state in Ular Naga does not have the benefit of developing language aspect on children. The respondent cannot describe Ular Naga as games that can develop the language aspect of children because they thought language correlated with reading or writing competencies. According to(Pramudyani, A. V. R., Kurniawan, M. R., Rasyid, H., Sujarwo, S., Utami, N. I., \& Rachmawati, 2018), Ular Naga has activities that can develop language aspect on children especially expressing language for example; expressing their happiness when they won the games and sadness when they got loose the game. In line with(Prihariyani, 2018), with Ular Naga the students can learn to express language in verbal.

Six, from the data obtained information all respondent know Ular Naga as games with the benefit of developing an aspect on children in a motor skill such as walking, running, catching, make a train, and make a line. This is in line with(Cahhya, M. S., Parmiti, D. P., \& Mahadewi, 2017), motor skills especially to develop coordination ability of head-hand-foot in children the teacher can use Ular Naga. Ular Naga as the methods for the teacher in developing motor skills on the child also supported statement from (Pramudyani, A. V. R., Kurniawan, M. R., Rasyid, H., Sujarwo, S., Utami, N. I., \& Rachmawati, 2018), to develop gross motor skills the children can do the walking, make turning right or left, move the hand and make a shape like a tunnel those activities they can do when playing Ular Naga. According to (Pramudyani, A. V. R., Kurniawan, M. R., Rasyid, H., Sujarwo, S., Utami, N. I., \& Rachmawati, 2018), Ular Naga also can develop fine motor skills on a child such as touching a friend's shoulder when making a line and holding hands when making a tunnel. However, from the data only few respondents know that fact. They had opinions, fine motor skills only can develop through activities such as drawing, colouring, writing, and activities in art.

Seven, all the respondent have the same argument that Ular Naga can develop social-emotional aspect on children through make a group on this games. Seven, all the respondent have the same argument that Ular Naga can develop social-emotional aspect on children through making a group on these games. Even though they can state Ular Naga can develop social-emotional aspect on children but they can explain more detail the benefit. Based on (Pramudyani, A. V. R., Kurniawan, M. R., Rasyid, H., Sujarwo, S., Utami, N. I., \& Rachmawati, 2018) and (Kurniati, 2016), social-emotional that can develop from Ular Naga not only cooperation in the group but also the children can managing their emotion when lose or win, practices leadership, and show their affection for their friends.

Based on the data, we can conclude that the majority of the respondent has thought traditional games Ular Naga have the benefit for children to develop gross motor skills and social-emotional aspects. However, they can give me an explanation holistically. They describe every aspect from what they see it without analysis more deeply based on the theory development early childhood. Even though only a few respondents can state that Ular Naga can be the methods for the teacher in developing all aspect of childhood development, we still have a chance to inspired the other.

The lack of knowledge of the respondent about Ular Naga has certain activities that can develop fine motor skills, language, cognitive, and social-emotional on children because they never had a chance to get training to improve their competences. According to (Maryatun, I. B., Pamungkas, J., \& Christianti, 2017), the data shows 91.5\% in Yogyakarta teacher had difficulties to develop local-based on their learning process due they never joint a specific training to develop competencies to utilizing learning theme based on local culture. Additionally, the lack of knowledge of the teachers in early childhood education about childhood development, creative learning, unutilized local culture because their qualification, some of them graduate from different major not specific in early childhood education, even they only graduate from senior high school. According to (Kementerian Pendidikan dan Kebudayan, 2018) from 7.310 teachers early cildhood education in Indonesia only 1.906 teachers graduate from bachelor but did not spesific all of them graduate from early childhood education program.

\section{CONCLUSION}

Ular Naga is one of the traditional game came from Yogyakarta can give benefit for children to develop their all aspects such as religious and moral values, cognitive, language, gross and motor skill, social-emotional. This games also can be the methods for the teacher in Early Childhood Education to create joyful learning. However, the majority of the teacher has a perspective that Ular Naga only can develop gross motor skills when 
the children walking, running, catching, make a train, and make a line and social-emotional aspects with activities build cooperative within friends in the group. However the teacher not yet explanation holistically all the aspect that should be can develop from Ular Naga.

The teacher does not know that Ular Naga has a lot of benefits for the children's aspects because they never had a chance to get training to improve their competences especially about childhood development, creative learning, utilizing local culture. To overcome this condition, the teacher through association or Gugus can make a cooperation with the university to hold on training especially about creating joyful learning with the local culture.

\section{REFERENCES}

Cahhya, M. S., Parmiti, D. P., \& Mahadewi, P. L. (2017). Pengaruh Metode Bermain Melalui Permainan Ular Naga Terhadap Kemampuan Motorik Kasar. Jurnal Pendidikan Anak Usia Dini Undiksha, 5(3), 285-294. https://doi.org/doi:http://dx.doi.org/10.23887/paud.v5i1.11505

Cahya, K. D., Mauliyana, A., Fitriyaningsih, R., Widayanti, T. A., Dewi, W. S., \& Noviani, E. H. (2019). Penerapan Mencuci Tangan Anak SD Dengan Metode Ular Naga. https://doi.org/doi:https://doi.org/10.31219/osf.io/bwv3r

Dharmamulya, dkk, S. (2005). Permainan Tradisional Jawa. Kepel Press.

Dharmamulya, S. (1993). Permainan Anak-anak Daerah Istimewa Yogyakarta(1st ed.). Depdikbud.

Kementerian Pendidikan dan Kebudayan, S. P. (2018). Statistik Persekolahan PAUD 2017/2018. http://publikasi.data.kemdikbud.go.id/uploadDir/isi_61EDBC51-02F3-4E9D-A45E-954CAF349570_.pdf

Kurniati, E. (2016). Permainan Tradisional dan Perannya Dalam Mengembangkan Keterampilan Sosial Anak (1st ed.). Prenada Group.

Maryatun, I. B., Pamungkas, J., \& Christianti, M. (2017). Kemampuan Guru TK di Yogyakarta Dalam Mengembangkan Tema Pembelajaran Berbasis Budaya Lokal. Jurnal Penelitian IImu Pendidikan, 101). https://doi.org/doi:10.21831/jpipfip.v10i1.16791

Miles, M. B., Huberman, M. A., \& Saldana, J. (2014). Qualitative Data Analysis: A Method Sourcebook (E. H. Salmon (ed.); Fourth Edi). SAGE Publication.

Nasrullah. (2015). Semiotic Progress in Traditional Game Based Number LEarning for Primary School Stdents. Cakrawala Pendidikan, 34(1), 368. https://journal.uny.ac.id/index.php/cp/article/view/7354/pdf

Pramudyani, A. V. R., Kurniawan, M. R., Rasyid, H., Sujarwo, S., Utami, N. I., \& Rachmawati, D. (2018). Buku Panduan Permainan Tradisional Berdasarkan Aspek Perkembangan Anak Ular Naga. Samudra Biru.

Pramudyani, A. V. R., Kurniawan, M. R., Rasyid, H., \& S. (2017). Kurikulum Holistik Integratif Berbasis Permainan Tradisional Pada PAUD Di Yogyakarta. Jurnal Penelitian Ilmu Pendidikan, 102), 86-96. https://doi.org/doi: 10.21831/jpipfip.v10i2.17910

Prihariyani, P. (2018). Peningkatan Kemampuan Berbicara Bahasa Inggris dengan Permainan Ular Naga Pada Siswa Kelas VII -J Semester 2 SMPN 3 Mranggen. Orbith: Majalah IImiah Pengembangan Rekayasa Dan Sosial, 14(3), 157-166. https://doi.org/doi:10.32497/orbith.v14i3.1313

Stojanovska, T. V., Connell, V. M., Malinovski, T., \& Trajkovik, V. (2014). The Traditional Prospect of Traditional Games as Learning Activities of Modern Students. 8th European Conference on Game Based LEerning, 749. http://toc.proceedings.com/24284webtoc.pdf

Suherman, W. S., Nopembri, S., \& Muktiani, N. R. (2017). Pengembangan "Majeda" Berbasis Dolanan Anak Untuk Mengoptimalkan Tumbuh Kembang Siswa TK. Cakrawala Pendidikan, 2, 220-232. doi:https://doi.org/10.21831/cp.v36i2.13542

Syafrina, M. (2014). Meningkatkan Perkembangan Sosial Anak melalui Permainan Ular Naga di PAUD Harapan Bangsa Kecamatan Sintuk Toboh Gadang Padang Pariaman. SPEKTRUM, 2(1), 49-59. https://doi.org/doi:https://doi.org/10.24036/spektrumpls.v2i1.5064

Ulker, R., \& Gu, W. (2004). Traditional Play: Chinesse and Turkish Examples. TASP Conference. 